\title{
Human hexokinase II gene: exon-intron organization, mutation screening in NIDDM, and its relationship to muscle hexokinase activity
}

\author{
M. Lehto ${ }^{1}$, X. Huang ${ }^{1}$, E. M. Davis ${ }^{2}$, M. M. Le Beau ${ }^{2}$, E.Laurila ${ }^{1}$, K. F. Eriksson ${ }^{1}$, G. I. Bel ${ }^{2,3}$, L. Groop ${ }^{1}$ \\ ${ }^{1}$ Department of Biochemistry, University of Helsinki, Finland; and Wallenberg Laboratories, Department of Endocrinology, \\ University of Lund, Malmö, Sweden \\ ${ }^{2}$ Department of Medicine, The University of Chicago, Chicago, Illinois, USA \\ ${ }^{3}$ Howard Hughes Medical Institute, and Department of Biochemistry and Molecular Biology, The University of Chicago, Chicago, \\ Illinois, USA
}

Summary In muscle, hexokinase II (HK2) regulates phosphorylation of glucose to glucose 6-phosphate, which has been reported to be impaired in patients with non-insulin-dependent diabetes mellitus (NIDDM). Here we report decreased HK2 enzyme activity in skeletal muscle biopsies from patients with impaired glucose tolerance compared with healthy control subjects $(2.7 \pm 0.9$ vs $4.9 \pm 1.1 \mathrm{nmol}$. $\min ^{-1} \cdot \mathrm{mg}$ protein $\left.{ }^{-1}\right)$. Therefore, mutations in the HK2 gene could contribute to skeletal muscle insulin resistance in NIDDM. To address this question, we first determined the exon-intron structure of the human HK2 gene and using this information, we screened all 18 exons with single-strand conformation polymorphism technique in 80 Finnish NIDDM patients. Nine nucleotide substitutions were found, one of which was a missense mutation ( $\mathrm{Gln}^{142}$-His ${ }^{142}$ ) in exon 4. In human muscle, a single HK2 mRNA transcript with a size of approximately 5500 nucleotides was detected with Northern blot analysis. We also describe an HK2 pseudogene (HK2P1), which was mapped to chromosome 4 , band q26, by fluorescence in situ hybridization to metaphase chromosomes. The clinical characteristics and HK2 enzyme activities of the subjects with either GIn or His at residue 142 did not differ from each other. Instead, HK2 activity correlated inversely with fasting blood glucose levels, suggesting that changes in HK2 activity could be secondary to other metabolic abnormalities $(r=0.55 ; p<0.0003 ; n=39)$. In conclusion; the data suggest that impaired HK2 activity in prediabetic individuals is a consequence of impaired glucose tolerance rather than of a genetic abnormality. The data thus seem to rule out mutations in the $\mathrm{HK} 2$ gene as a major cause of inherited insulin resistance in NIDDM. [Diabetologia (1995) 38: 14661474]

Key words Glucose, phosphorylation, glycolysis, insulin resistance, non-insulin-dependent diabetes mellitus, genetics, chromosome 4.
Hexokinase (ATP: D-hexose 6-phosphotransferase, EC 2.7.1.1) is an intracellular enzyme which catalyses the phosphorylation of glucose to glucose 6-phos-

Received: 30 January 1995 and in revised form: 26 June 1995

Corresponding author: Dr. M. Lehto, Wallenberg Laboratory, Department of Endocrinology, University of Lund, Malmö General Hospital, S-21401 Malmö, Sweden

Abbreviations: IGT, Impaired glucose tolerance; NIDDM, non-insulin-dependent diabetes mellitus; HK2, hexokinase II; HK1, hexokinase I; PCR, polymerase chain reaction; FISH, fluorescence in situ hybridization; STRP, simple tandem repeat polymorphism; HK2PI, hexokinase II pseudogene; SSCP, single-strand conformation polymorphism; bp, base pair. phate, the first rate-limiting reaction in the cellular metabolism of glucose. In mammals, four hexokinase isoforms have been described which vary in their tissue distribution and kinetic properties [1]. Recent studies have shown that mutations in glucokinase (hexokinase IV) can cause maturity-onset diabetes of the young (MODY), a form of non-insulindependent diabetes mellitus (NIDDM) characterized by onset before 25 years of age and autosomal dominant inheritance [2-5]. This suggests that mutations in other forms of hexokinase may also contribute to the development of NIDDM. Among them, hexokinase II (HK2) is a particularly attractive candidate because it is expressed in muscle [1] and insulin 
resistance in muscle is a typical feature of NIDDM [6]. The molecular basis of insulin resistance is unclear but decreased levels of glucose 6-phosphate in muscle tissue of insulin-resistant subjects suggest that mutations in the HK2 gene, which affect its activity or expression, might contribute to the development of insulin resistance and diabetes mellitus [7]. We have previously localized HK2 to chromosome band $2 \mathrm{p} 13$ [8] and shown that HK2 is not linked to MODY $[9,10]$. However, these studies did not exclude a role for HK2 in the development of the more common late-onset form(s) of NIDDM which is probably oligo- or polygenic in origin with variation in several different genes contributing to diabetes susceptibility. To address this question, we isolated the HK2 gene and screened all 18 exons for mutations in 80 unrelated Finnish NIDDM subjects who had documented insulin resistance. Furthermore we measured HK enzyme activities in muscle biopsies from prediabetic insulin-resistant individuals and related them to polymorphic variants in the HK2 gene.

\section{Subjects materials and methods}

Subjects. Eighty (39 male/41 female) Finnish unrelated NIDDM patients were included in the primary mutation screening of the HK2 gene. An additional 55 control subjects (23 male/32 female) from the same region were used in the evaluation of the allele frequencies. A standard (75 g) oral glucose tolerance test was performed in all subjects. The NIDDM patients were selected from a large cohort of NIDDM patients (the Botnia study) to fulfill the following criteria of insulin resistance: body mass index (BMI) $>27 \mathrm{~kg} / \mathrm{m}^{2}$, fasting serum insulin $>90 \mathrm{pmol} / \mathrm{l}$ or insulin resistance determined by a euglycaemic insulin clamp [6]. The clinical characteristics (mean \pm $\mathrm{SD}$ ) of the NIDDM patients and control subjects were as follows: age ( $67 \pm 10$ and $52 \pm 13$ years), fasting blood glucose levels $(9.1 \pm 2.9$ and $4.9 \pm 0.5 \mathrm{mmol} / \mathrm{l})$, fasting insulin levels $(133 \pm 120$ and $53 \pm 28 \mathrm{pmol} / \mathrm{l}), 2-\mathrm{h}$ insulin levels $(504 \pm 310$ and $259 \pm 137 \mathrm{pmol} / \mathrm{l}), \mathrm{HbA}_{1}(8.3 \pm 2.0$ and $5.4 \pm 0.4 \%), \mathrm{BMI}$ $\left(30.1 \pm 5.6\right.$ and $\left.25.9 \pm 4.0 \mathrm{~kg} / \mathrm{m}^{2}\right)$, serum triglyceride concentrations $(2.07 \pm 1.17$ and $1.19 \pm 0.65 \mathrm{mmol} / \mathrm{l})$, cholesterol $(6.06 \pm$ 1.51 and $5.57 \pm 1.44 \mathrm{mmol} / \mathrm{l})$ and serum HDL-cholesterol $(1.24 \pm 0.32$ and $1.44 \pm 0.35 \mathrm{mmol} / 1)$.

Hexokinase enzyme activities were measured from muscle biopsies taken from 41 Swedish male subjects (10 control subjects and 29 patients with impaired glucose tolerance [IGT]) after a 2 -h euglycaemic hyperinsulinaemic clamp. Clinical parameters of these subjects are shown in Table 1.

Isolation and characterization of HK2 $\mathrm{cDNA}$ and genomic clones. HK2 cDNA clones were isolated by hybridization from a human muscle cDNA library (Clontech, Palo Alto, Calif., USA; cat. no. HL1124A) with a ${ }^{32}$ P-labelled rat HK2 cDNA probe corresponding to nucleotides $1775-2440$. Thirteen clones ( $\lambda \mathrm{cHM}-1$ to -13 ) were isolated. The 3.2 kilobase (kb) EcoRI insert in $\lambda \mathrm{cHM}-11$ encoding amino acids $42-917$ and 3 '-untranslated region of the mRNA was used to rescreen the same cDNA library and to screen a human genomic library (Stratagene, La Jolla, Calif., USA; cat. no. 943202). Thirty-seven clones $(\lambda \mathrm{cHM}-14$ to -50$)$ were obtained from the cDNA li-
Table 1. Clinical characteristics and insulin-stimulated HK 1 and HK 2 enzyme activities in muscle biopsies taken from IGT and control subjects

\begin{tabular}{|c|c|c|}
\hline & Control subjects & IGT subjects \\
\hline$n$ & 10 & 29 \\
\hline Age (years) & $66 \pm 2$ & $66 \pm 3$ \\
\hline $\mathrm{BMI}\left(\mathrm{kg} / \mathrm{m}^{2}\right)$ & $28.5 \pm 4.0$ & $27.1 \pm 2.9$ \\
\hline $\begin{array}{l}\text { Fasting blood glucose } \\
(\mathrm{mmol} / \mathrm{l})\end{array}$ & $4.4 \pm 0.3$ & $6.2 \pm 1.6$ \\
\hline 2 h-glucose (mmol/l) & $\mathrm{ND}$ & $11.4 \pm 3.4$ \\
\hline M-value $\left(\mathrm{mg} \cdot \mathrm{kg}^{-1} \cdot \mathrm{min}^{-1}\right)$ & $4.30 \pm 2.44$ & $3.36 \pm 2.29$ \\
\hline $\begin{array}{l}\text { Total protein concentration } \\
(\mathrm{mg} / \mathrm{ml})\end{array}$ & $9.2 \pm 1.4$ & $9.3 \pm 1.9$ \\
\hline $\begin{array}{l}\text { Total hexokinase activity } \\
\left(\mathrm{nmol} \cdot \mathrm{min}^{-1} \cdot \mathrm{mg}^{-1} \text { protein }\right.\end{array}$ & $11.4 \pm 2.3$ & $6.0 \pm 1.3^{\mathrm{a}}$ \\
\hline 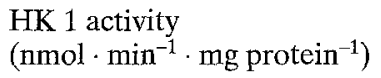 & $6.4 \pm 1.9$ & $3.4 \pm 0.9^{a}$ \\
\hline $\begin{array}{l}\text { HK } 2 \text { activity } \\
\left(\text { nmol } \cdot \text { min }^{-1} \cdot \text { mg protein }^{-1}\right)\end{array}$ & $4.9 \pm 1.1$ & $2.7 \pm 0.9^{\mathrm{a}}$ \\
\hline
\end{tabular}

Results are given as mean \pm SD. " Mann-Whitney test, $p<0.0001$. ND, not determined

brary and 23 clones ( $\lambda \mathrm{gHKG}-1$ to -23 ) from the genomic library. The genomic clones were further hybridized with ${ }^{32} \mathrm{P}-\mathrm{la}-$ belled poly $(\mathrm{dA}-\mathrm{d} \mathrm{C}) /(\mathrm{dG}-\mathrm{dT})$ probe (Pharmacia LKB Biotechnology, Piscataway, N.J., USA) to identify those containing CA-repeat rich regions. The insert in $\mathrm{cDNA}$ clone $\lambda \mathrm{cHM}$ 39 (aa 1-260) was used to screen a second genomic library (Stratagene, cat. no. 946205) in order to isolate the region of the gene corresponding to exons $1-7$, and $\lambda \mathrm{gGEN}-1$ to -22 were isolated. The cDNA and genomic clones were sequenced after subcloning appropriate restriction fragments into pGEM-4Z (Promega, Madison, Wis., USA) using Sequenase version 2.0 (United States Biochemical Corp., Cleveland, Ohio, USA).

Fluorescence in situ chromosomal hybridization. Human cells in metaphase were prepared from phytohaemagglutinin-stimulated peripheral blood lymphocytes. Fluorescence in situ hybridization (FISH) was performed as described previously [11] using biotin-labelled $\lambda$ gHKG-9 which has an insert of approximately 14 kilobase pairs. Hybridization was detected with fluorescein-conjugated avidin (Vector Laboratories, Burlingame, Calif., USA) and chromosomes were identified by staining with 4,6-diamidino-2-phenylindole dihydrochloride.

Amplification of simple tandem repeat polymorphisms in HK2 gene and pseudogene. Sequence analysis of the HK2 genomic clone $\lambda \mathrm{gHKG}-10$ revealed an AT-repeat rich region in intron 13. Two primers, HK-AT1 (5'- CTAGGCAACATAGGAAGA CC-3') and HK-AT2 (5'-AAACCTAACATAGTACCTGGC-3'), were used to amplify this repeat. The polymerase chain reactions (PCR) were carried out in a volume of $15 \mu 1$ containing $20 \mathrm{ng}$ of genomic DNA, 3 pmol of ${ }^{32} \mathrm{P}$-labelled HK-AT2, $3 \mathrm{pmol}$ of unlabelled HK-AT1, $200 \mu \mathrm{mol} / 1 \mathrm{dNTP}$, $1.5 \mathrm{mmol} / \mathrm{l} \mathrm{MgCl}_{2}, 0.5$ units of Taq DNA polymerase (Promega), $16 \mathrm{mmol} / \mathrm{l}$ ammonium sulphate, $67 \mathrm{mmol} / 1$ Tris- $\mathrm{HCl}, \mathrm{pH}$ 8.8 , and $0.01 \%$ Tween- 20 . The PCR was initiated with denaturation at $94^{\circ} \mathrm{C}$ for $5 \mathrm{~min}$, followed by 30 cycles of denaturation at $94^{\circ} \mathrm{C}$ for $30 \mathrm{~s}$, annealing at $58^{\circ} \mathrm{C}$ for $30 \mathrm{~s}$, extension at $72^{\circ} \mathrm{C}$ for $30 \mathrm{~s}$, and a final extension at $72^{\circ} \mathrm{C}$ for $10 \mathrm{~min}$. The PCR products were separated on a $5 \%$ denaturing polyacrylamide 
Table 2. Sequences of the primers used for amplification of the human HK2 exons, fragment sizes, and PCR conditions

\begin{tabular}{|c|c|c|c|c|c|}
\hline Exon & Upstream primer & Downstream primer & $\begin{array}{l}\text { Size } \\
\text { (bp) }\end{array}$ & $\begin{array}{l}\text { Annealing } \\
\text { temperature/time } \\
\left({ }^{\circ} \mathrm{C} / \mathrm{s}\right)\end{array}$ & $\begin{array}{l}\mathrm{MgCl}_{2} \\
(\mathrm{mmol} / \mathrm{l})\end{array}$ \\
\hline $5-\mathrm{UT}^{\mathrm{a}}$ & 5'CCACATTGTTGCATGAAACTCC & 5'-GCACAAAGAAGGCTACCGG & 327 & $59 / 40$ & 1.5 \\
\hline 2 & 5'-TTTCTGCTCTTGTCTTCCTCC & 5'-AGCCAGGGTTGGTTTCTGAG & 300 & $59 / 60$ & 2.5 \\
\hline 3 & 5'TAAGTCTCGGTTGGTTCCTGG & 5'-GAGCGGCTGGAGAAGTACAG & 294 & $61 / 60$ & 1.5 \\
\hline 4 & 5'-AGTTACGTGCTGAGCCTGAAG & 5'CTCAGAAGTCCCTCTCAGCC & 275 & $62 / 40$ & 1.5 \\
\hline 7 & 5'TTAGACCATGTATTGTGATGCC & 5'-AGCCCACTCGCACAGGAAG & 362 & $60 / 60$ & 1.5 \\
\hline 8 & 5'-AAGCTATGAGTACATGGGCAG & 5'-CGTCAACTCGTGTGGTGATC & 266 & $59 / 40$ & 1.5 \\
\hline 9 & 5'-CACATGCTGTCTTTCTGTTTCC & 5'-TACTCCAGGAACTCCGCATC & 303 & $59 / 60$ & 1.5 \\
\hline 10 & 5'-CATGGACACCTGTCGCTTAC & 5'CATGTGAGCCAGGTGGCAAC & 376 & $61 / 60$ & 1.5 \\
\hline 11 & 5'-AGTGTACTGTCTCCACATTCC & 5'-AAAGCACTGTCCTCGAAGGC & 285 & $59 / 40$ & 1.5 \\
\hline 12 & 5'-CTCAGTGTCCTAACTTCTCC & 5'-TAAAGCCCACAGGAGAGCC & 185 & $58 / 30$ & 1.5 \\
\hline 17 & 5'TGGTGCATGACTGAACACTTG & 5'-AGACAGAAAGAAGGTAGGCAG & 320 & $59 / 60$ & 1.5 \\
\hline 18 & 5'-TTCCAGCATCGCTTCTTAGC & 5'-TCTACAATGAGATGCAGAGAC & 397 & $57 / 60$ & 1.5 \\
\hline
\end{tabular}

${ }^{a}$ Primers used for amplification of the $5^{\prime}$-untranslated region.

gel. A simple tandem repeat polymorphism (STRP) in the region of the HK2 pseudogene HK2P1 was amplified with primers HKP-1 (5'-TCCTCTAGAACCACTCCTTG-3') and HKP-2 (5'-TACAGACAGCCTATTGTGAG-3'). The PCR was carried out in a volume of $15 \mu \mathrm{l}$ using ${ }^{32} \mathrm{P}$-labelled HKP-1 as described above and 35 cycles of denaturation at $94^{\circ} \mathrm{C}$ for $30 \mathrm{~s}$, annealing at $57^{\circ} \mathrm{C}$ for $30 \mathrm{~s}$, extension at $72^{\circ} \mathrm{C}$ for $45 \mathrm{~s}$, and a final extension at $72^{\circ} \mathrm{C}$ for $10 \mathrm{~min}$.

Single-strand conformation polymorphism analysis. Singlestrand conformation polymorphism analysis (SSCP) was performed as described [12] with the following modifications. The PCR was carried out in a volume of $20 \mu 1$ including $30 \mathrm{ng}$ of genomic DNA, 8 pmol of each primer, $0.5 \mathrm{U}$ of Taq DNA polymerase, and $0.1 \mu 1$ of $\left[\alpha_{-}{ }^{32} \mathrm{P}\right] \mathrm{dCTP}(3000 \mathrm{Ci} / \mathrm{mmol}$; Amersham, Amersham, Bucks., UK). The primer sequences and PCR conditions are noted in Table 2 . The PCR products were diluted $1: 1$ with $20 \mathrm{mmol} / \mathrm{l}$ EDTA (pH 8.0 ) and $0.2 \%$ sodium dodecyl sulphate (SDS) solution. Before loading on the gel, samples were mixed 1:1 with formamide and heat-denatured at $90^{\circ} \mathrm{C}$ for $5 \mathrm{~min}$. All samples were run on non-denaturing $5 \%$ acrylamide gel (acrylamide/bisacrylamide 60:1) without and with $5 \%$ glycerol. The gels were electrophoresed at $10 \mathrm{~W}$ for $8-16 \mathrm{~h}$ at room temperature. Samples which had a different migration pattern were further analysed by direct sequencing of the PCR product. The allelic variations of $\mathrm{Gln}^{142} \mathrm{His}$ mutation were determined by restriction site-generating PCR as previously reported [13].

$R N A$ blotting. RNA was isolated from a muscle biopsy taken in the basal state from the vastus lateralis muscle of a 32-year-old healthy man. The biopsy specimen was immediately placed into liquid nitrogen and stored at $-70^{\circ} \mathrm{C}$ until analysed. Muscle samples were also taken from the hind limb of ad libitum-fed male Sprague-Dawley rats. The human muscle sample (36 $\mathrm{mg}$ ) and two rat samples ( 34 and $45 \mathrm{mg}$ ) were homogenized in $700 \mu \mathrm{l}$ of ice-cold extraction buffer ( $4 \mathrm{~mol} / 1$ guanidinum thiocyanate, $25 \mathrm{mmol} / 1$ sodium citrate $\mathrm{pH} 7.0,1 \%$ Nonidet $\mathrm{P}-40$, and $1 \% \beta$-mercaptoethanol). Samples were extracted with phenol and chloroform/isoamyl alcohol (24:1) and ethanol precipitated at $-20^{\circ} \mathrm{C}$ for $16 \mathrm{~h}$. Total human $(32.2 \mu \mathrm{g})$ and rat $(25.5$

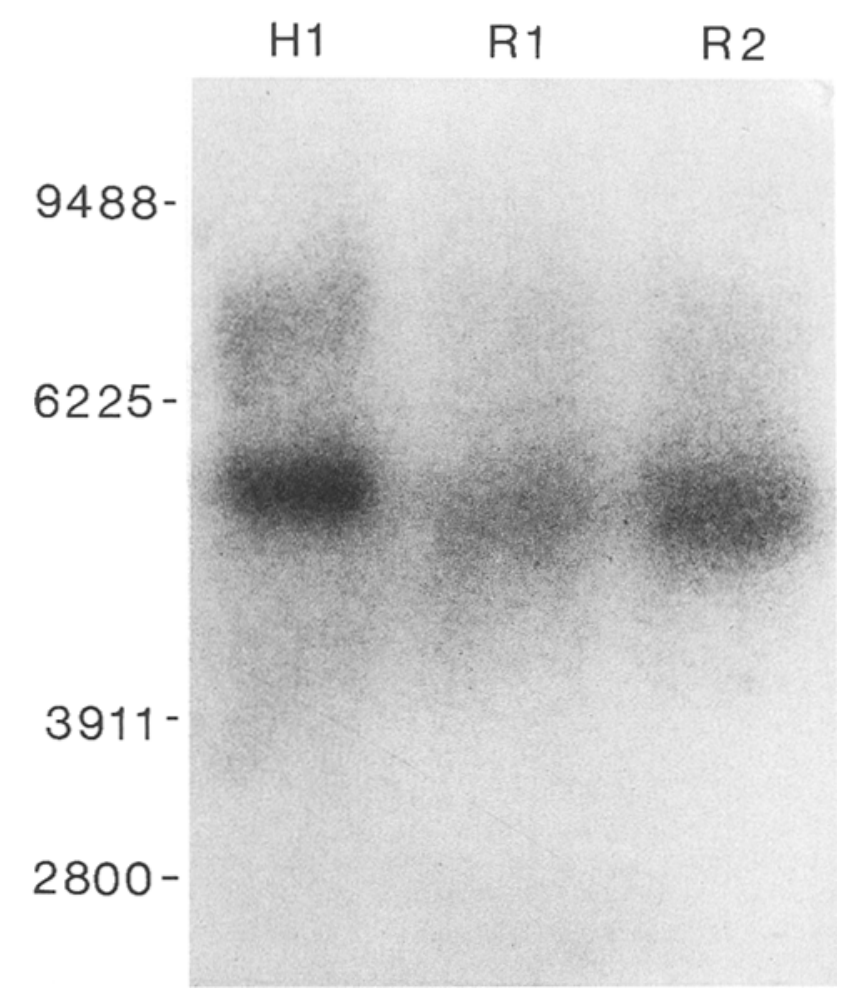

Fig. 1. Northern blot analysis of HK2 mRNA from muscle. H1, Human; R1 and R2, rat. The sizes of the RNA standards are noted

and $33.5 \mu \mathrm{g})$ RNAs were fractionated by electrophoresis in a formaldehyde-containing gel [14]. The RNA was transferred to a nitrocellulose membrane (Hoefer Scientific Instruments, San Francisco, Calif., USA), which was hybridized with ${ }^{32} \mathbf{P}-1 \mathrm{a}-$ belled insert from the human HK2 cDNA clone, $\lambda \mathrm{cHM}-11$; the filter was washed in $0.1 \times \mathrm{SSC} / 0.1 \% \mathrm{SDS}$ at $50^{\circ} \mathrm{C}$ before exposure to $\mathrm{X}$-ray film. 

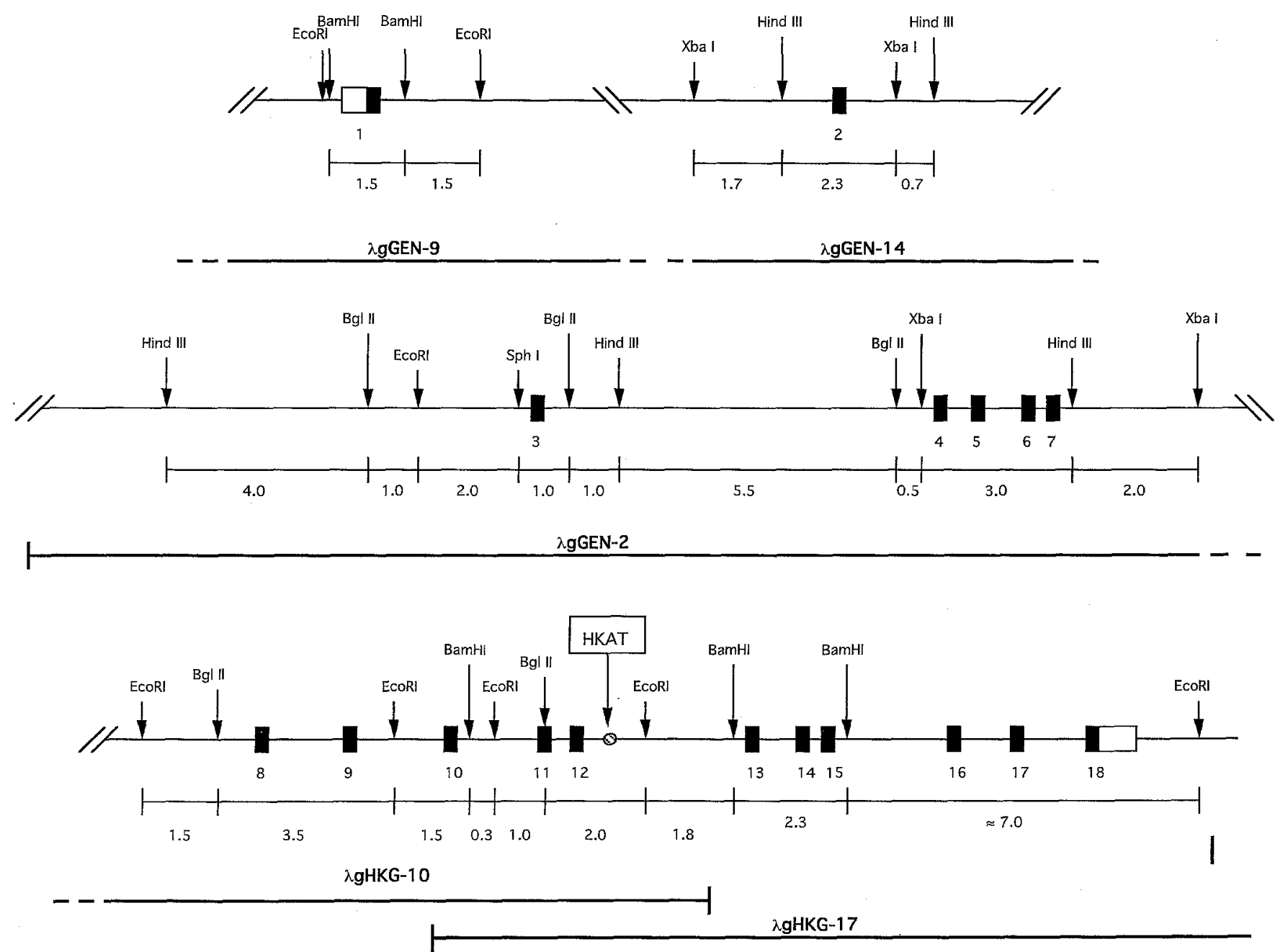

Fig. 2. Organization of the human HK2 gene. The structure of the genomic clones and the locations of the exons are indicated. The location of the AT-rich STRP (HKAT) is also indicated

Determination of muscle HK1 and HK2 enzyme activities after 2-h insulin-stimulated clamp. Muscle biopsies were taken under local anaesthesia with a Bergström needle from the vastus lateralis muscle in 29 IGT and 10 control subjects at the end of a 2-h euglycaemic hyperinsulinaemic clamp (insulin infusion $45 \mathrm{mU} \cdot \mathrm{m}^{-2} \cdot \mathrm{min}^{-1}$ ) [15]. Muscle samples were homogenized (10 mg muscle/100 $\mu \mathrm{l}$ homogenizing reagent: $50 \mathrm{mmol} / \mathrm{l}$ Tris$\mathrm{HCl} \mathrm{pH} 7.4,0.5 \mathrm{mmol} / \mathrm{I} \mathrm{DTT}, 1 \mathrm{mmol} / \mathrm{LDTA}$, and $2 \mathrm{mmol} / \mathrm{l}$ $\mathrm{MgCl}_{2}$ ) with ground glass homogenizer on ice. Ability to separate HK1 and HK2 enzyme activities is based on different temperature sensitivities of these two isoforms [1]. One sample was kept on ice in order to measure total hexokinase enzyme activity (HK1 $+\mathrm{HK} 2)$ while the other sample was heated at $45^{\circ} \mathrm{C}$ for $1 \mathrm{~h}$ in order to eliminate HK2 enzyme activity. The hexokinase enzyme activities were determined with enzymelinked fluorometric assay. Five microlitre sample homogenate was mixed with $505 \mu \mathrm{l}$ assay buffer consisting of $50 \mathrm{mmol} / 1$ Tris- $\mathrm{HCl} \mathrm{pH} 7.4,0.02 \%$ bovine serum albumin, $2 \mathrm{mmol} / \mathrm{I}$ ATP, $5 \mathrm{mmol} / 1 \mathrm{MgCl} 2,0.3 \mathrm{mmol} / 1 \mathrm{NADP}, 1 \mathrm{mmol} / 1 \mathrm{EDTA}$, $1 \mathrm{mmol} / \mathrm{L} \mathrm{DTT}, 1 \mathrm{mmol} / 1$ glucose, and $0.14 \mathrm{U} / \mathrm{ml}$ glucose 6 phosphate dehydrogenase (Boehringer Mannheim, Mann- heim, Germany). Fluorescence was measured with a fluorometer (Transcon $102 \mathrm{FN}$ analyser; Orion Analytica, Helsinki, Finland) for $15 \mathrm{~min}$. Protein content was assayed in the homogenate according to Lowry et al. [16], and the enzyme activities expressed as nmol $\cdot \mathrm{min}^{-1} \cdot \mathrm{mg}_{\text {protein }}{ }^{-1}$.

\section{Statistical analysis}

Yates' corrected chi-squared $\left(\chi^{2}\right)$ test was used to estimate differences between allele frequencies. Significances of differences between means of clinical parameters were analysed with Student's $t$-test. If the distribution of the parameter was not normal, a nonparametric Mann-Whitney test was used instead. Values of $p<0.05$ were considered to be significant.

\section{Results}

Sequence of human HK2 cDNA. The sequence of human HK2 mRNA was deduced from the composite sequences of the inserts in three overlapping clones $\lambda \mathrm{cHM}-3, \lambda \mathrm{cHM}-11$ and $\lambda \mathrm{cHM}-39$ (EMBL accession no. Z46376). RNA blotting studies showed a single transcript of $\sim 5500$ nucleotides in human muscle (Fig.1). The size of rat HK2 mRNA was estimated to 


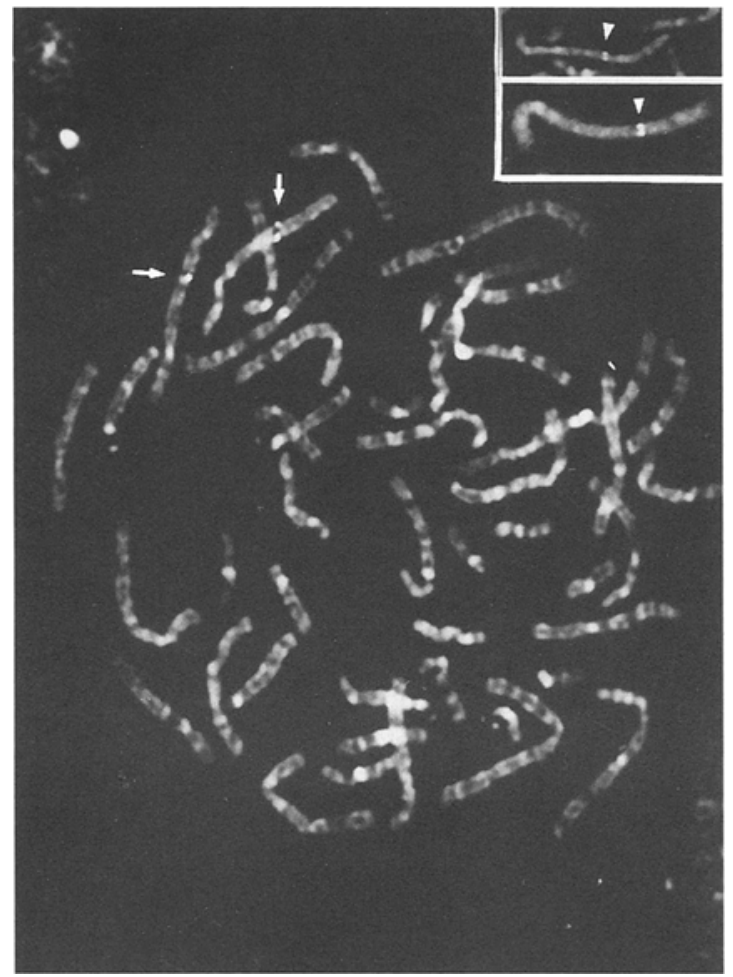

Fig. 3. Chromosomal localization of HK2P1 by fluorescence in situ hybridization. The hybridization of biotin-labelled $\lambda$ gHKG-9 DNA to normal human cells in metaphase from phytohaemagglutinin-stimulated peripheral blood lymphocytes is shown. The chromosome 4 homologues are identified with arrows. Specific labelling was observed at chromosome band $4 \mathrm{q} 26$. The inset shows partial karyotypes of two chromosome 4 homologues illustrating specific labelling at $4 \mathrm{q} 26$ (arrowheads). Images were obtained using Zeiss Axiphot microscope coupled to a cooled charge-coupled-device camera. Separate images of 4,6-diamidino-2-phenylindole dihydrochloride DAPI-stained chromosomes and the hybridization signal were merged using image analysis software (NU200 and Image1.52b)

be -5300 nucleotides which agrees well with previous estimates of $\sim 5200$ nucleotides [17].

Our human HK2 mRNA sequence is similar to that previously reported by Deeb et al. [18] with the following differences (published/our sequence): Ser12 (TCG)/Thr12 (ACG); Glu106 (GAA)/Glu106 (GAG); Arg405 (CGC)/Arg405 (CGG); Ala406 (GCT)/Leu406 (CTG); Ala634 (GCG)/Val634 (GTG); Asn692 (AAT)/Asn692 (AAC); Ala711 (GCA)/Ala711 (GCC); Leu766 (CTG)/Leu766 (CTA); and Ile803 (ATC)/Thr803 (ACC). The studies described below indicate that the silent mutations in the codons for Asn692 and Leu766 are common polymorphisms; the basis for the other sequence differences (i.e. sequence or cloning errors) is unknown.

Isolation and characterization of the human HK2 gene. HK2 was isolated as a series of overlapping clones in lambda phage. The gene consists of 18 exons that span more than $50 \mathrm{~kb}$ (Fig. 2); the actual size of the gene is unknown because of gaps of undetermined size in introns 1,2 and 7 . The sequences of the 18 exons were determined (EMBL accession no. Z46604, Z46354-Z46369). The introns interrupt the gene in identical positions to those previously determined for the corresponding rat gene [19]. Exon-intron sequences determined here were identical with previously published results [20,21].

Isolation and chromosomal localization of an HK2 pseudogene. The sequence of the insert in the genomic clone $\lambda \mathrm{gHKG}-9$ (EMBL accession no. Z46370) was $96 \%$ identical to exons $1-7$ of HK2. In contrast to $\mathrm{HK} 2$, this sequence was not interrupted by introns suggesting that $\lambda \mathrm{gHKG}-9$ corresponded to a HK2-pseudogene, designated HK2P1. The chromosomal localization of the HK2P1 was determined by hybridization of biotin-labelled $\lambda \mathrm{gHKG}-9$ DNA to normal human chromosomes in metaphase. The FISH results showed specific labelling of chromosome 4 (Fig. 3) and of the X chromosome. Specific labelling of $4 \mathrm{q} 26-\mathrm{q} 28$ was observed on four (eight cells), three (nine cells), or two (8 cells) chromatids of the chromosome 4 homologues in 25 cells examined. Of the 103 signals observed ( 75 of $1004 \mathrm{q}$ chromatids from 25 cells in metaphase were labelled), 62 $(60 \%)$ signals were located at $4 \mathrm{q} 26$, and $13(13 \%)$ were at $4 \mathrm{q} 28$. Fourteen signals $(13.5 \%)$ were located at Xq21.1, three single signals were located at $11 \mathrm{p} 12$, and the remaining 11 single signals were localized to other random chromosomal sites. Specific signals were also observed at 4q26-q28 in a second FISH experiment using this same probe; 42 of 45 signals observed in 18 cells were located at 4q26-q28. Hybridization of the probe to $\mathrm{Xq} 21.1$ was not observed in this experiment. The results of FISH analysis suggest that HK2P1 is located at $4 \mathrm{q} 26$.

Characterization of STRPs in HK2 gene and pseudogene. Sequence analysis of the HK2 clone gHKG-10 revealed an STRP of the form (AT)n (EMBL accession no. Z46377) in intron 13 approximately 500 base pairs (bp) downstream from exon 12 (HKAT in Fig. 2). In an analysis of 42 unrelated healthy non-diabetic Finnish subjects, this STRP showed 17 alleles and polymorphism information content of 0.79 (Table 3). An STRP of the form (CA)n (EMBL accession no. Z46378) was identified in the HK2P1 clone $\lambda$ gHKG-9. Twenty alleles were noted on typing 42 unrelated subjects (Table 3 ). These STRPs could be useful in genetic linkage studies of these loci in diabetes mellitus and other disorders.

Screening of HK2 for mutations in subjects with NIDDM. SSCP was used to screen HK2 for mutations in a group of 80 unrelated insulin-resistant Finnish subjects with NIDDM (Fig.4). Two different gel conditions were used: $5 \%$ non-denaturing polyacry- 
Table 3. Allele frequencies of HK2 and HK2P1 STRPs as determined in 42 unrelated Finnish healthy subjects

\begin{tabular}{|c|c|c|c|c|c|c|c|}
\hline HK2 allele & Size (bp) & Number of alleles & Allele frequency & HK2P1 Allele & Size (bp) & Number of alleles & Allele frequency \\
\hline 1 & 151 & 2 & 0.02 & 1 & 340 & 1 & 0.01 \\
\hline 2 & 149 & 1 & 0.01 & 2 & 338 & 1 & 0.01 \\
\hline 3 & 147 & 3 & 0.04 & 3 & 336 & 3 & 0.04 \\
\hline 5 & 143 & 5 & 0.06 & 5 & 332 & 2 & 0.02 \\
\hline 6 & 141 & 4 & 0.05 & 6 & 330 & 6 & 0.07 \\
\hline 7 & 139 & 4 & 0.05 & 7 & 328 & 4 & 0.05 \\
\hline 10 & 133 & 1 & 0.01 & 10 & 268 & 2 & 0.02 \\
\hline 11 & 131 & 1 & 0.01 & 11 & 266 & 1 & 0.01 \\
\hline 12 & 127 & 2 & 0.02 & 12 & 264 & 5 & 0.06 \\
\hline 13 & 125 & 3 & 0.04 & 13 & 262 & 4 & 0.05 \\
\hline 14 & 123 & 4 & 0.05 & 14 & 260 & 19 & 0.23 \\
\hline 15 & 121 & 5 & 0.06 & 15 & 258 & 4 & 0.05 \\
\hline
\end{tabular}

\begin{tabular}{llll}
\hline Heterozygosity $=0.80$ & PIC $=0.79$ & Heterozygosity $=0.89$ & PIC $=0.89$
\end{tabular}

PIC, Polymorphism information content

Table 4. Nucleotide substitutions in HK2

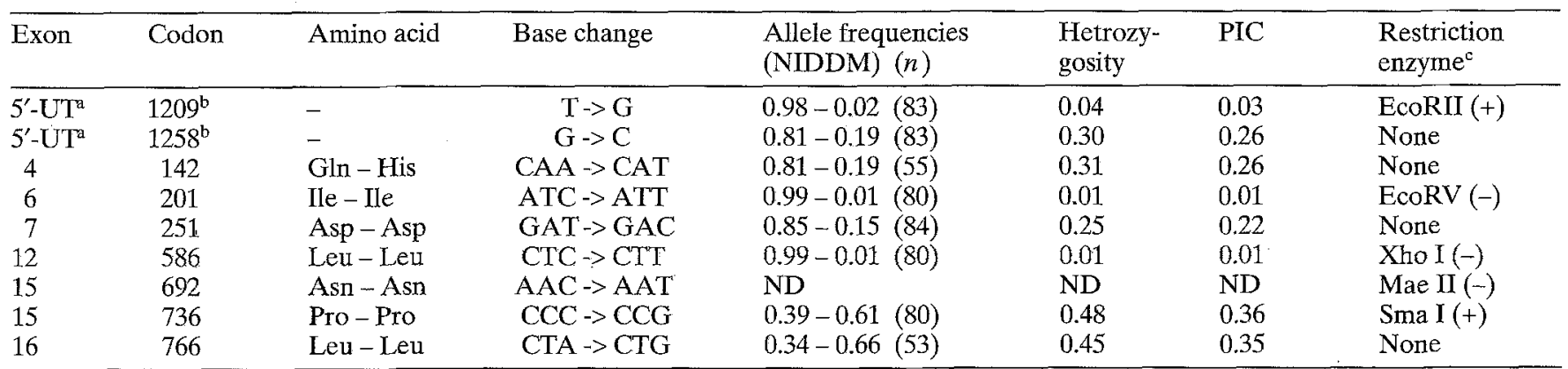

Heterozygosity and PIC-values were determined using allele frequencies of the NIDDM patients. ${ }^{a} 5^{\prime}$-untranslated region; ${ }^{\mathrm{b}}$ nucleotide position in cDNA; ${ }^{\mathrm{C}}$ Restriction enzyme recogni- tion site created $(+)$ or removed $(-)$ by the nucleotide change. ND, Not determined; PIC, polymorphism information content lamide (acrylamide: bis $=60: 1$ ) gel with and without $5 \%$ glycerol. It is not clear whether these conditions will identify all possible mutations. However, the identification of nucleotide substitutions in seven of 18 exons, including exon 15, which was the largest PCR product ( $427 \mathrm{bp}$ ) suggests that we were unlikely to have missed a large number of substitutions. Nine nucleotide substitutions were identified in the HK2 gene, two of which were in the $5^{\prime}$-untranslated region of HK2 mRNA and the remaining seven were in the protein coding portion of the gene (Table 4). Six of the latter substitutions were silent mutations and one was a conservative amino acid replacement $\mathrm{GIn}^{142}$ (CAA) to His ${ }^{142}$ (CAT). The frequency of the Gln $^{142}$ and $\mathrm{His}^{142}$ alleles of HK2 was not significantly different $(p=0.47)$ between 55 control ( $\mathrm{Gln}-0.85 /$ His-0.15) and 55 NIDDM subjects (Gln - 0.81/ His - 0.19). Moreover, the clinical and metabolic characteristics did not differ between NIDDM or control groups with $\mathrm{Gln}^{142}$ or His ${ }^{142}$ polymorphism (Table 5).

HKI and HK2 enzyme activities in muscle. The IGT and control groups were matched for age and BMI. The IGT patients had significantly lower total hexokinase activity than the control subjects, which was due to a reduction in both $\mathrm{HK} 1$ and $\mathrm{HK} 2$ activities (Table 1). Total hexokinase $(6.2 \pm 0.8$ vs $5.3 \pm 0.9$ $\mathrm{nmol} \cdot \mathrm{kg}^{-1} \cdot \mathrm{mg}$ protein $\left.{ }^{-1} ; p=0.015\right)$ and HK2 (2.9 0.9 vs. $2.3 \pm 0.7 \mathrm{nmol} \cdot \mathrm{kg}^{-1}$ protein ${ }^{-1} ; p=0.051$ ) activities were slightly higher in IGT patients with than those without a first-degree family history of NIDDM. To examine whether the $\operatorname{Gln}^{142}$ His polymorphism has an influence on hexokinase enzyme activity in muscle, we measured the muscle HK2 enzyme activity in 28 IGT patients and subdivided them into two groups according to the genotypic variants $(\mathrm{Gln} / \mathrm{Gln}=1$, and $\mathrm{Gln} / \mathrm{His}$, His/His =2). As seen 
A

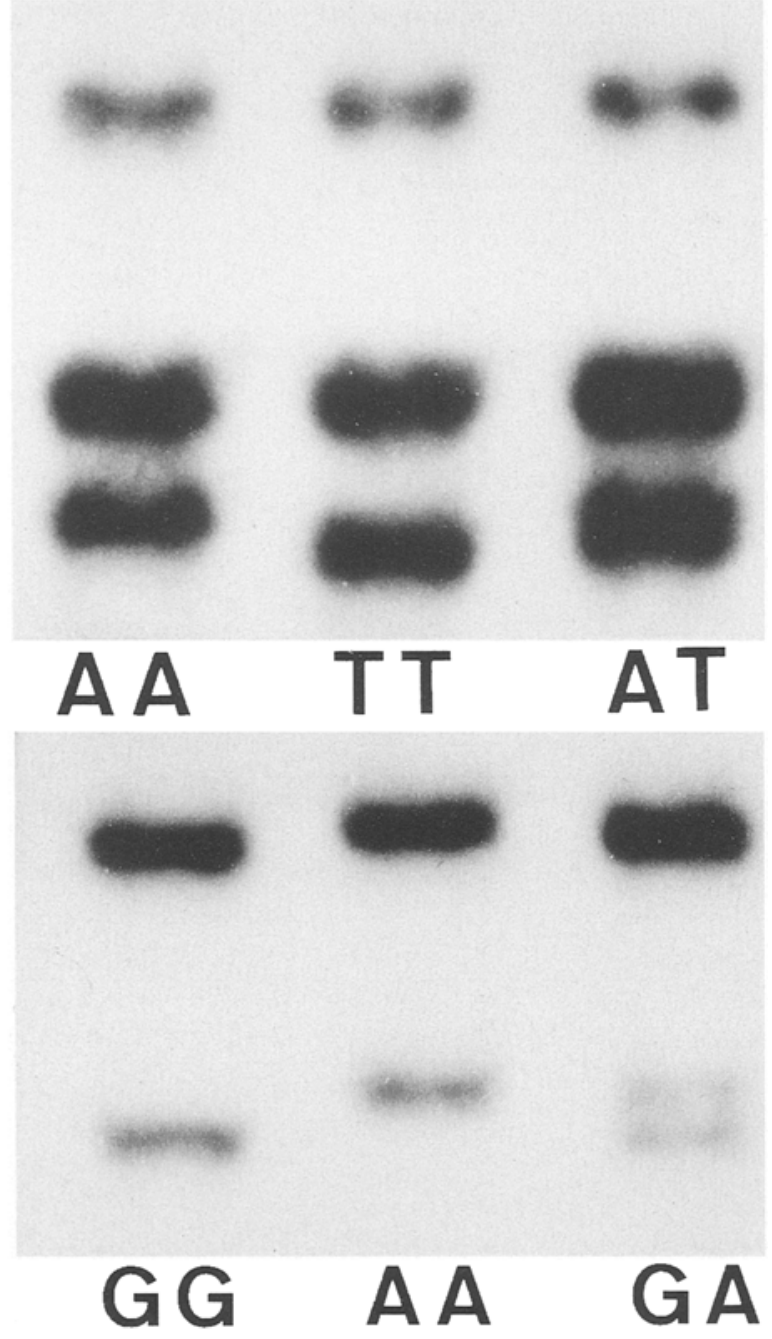

B

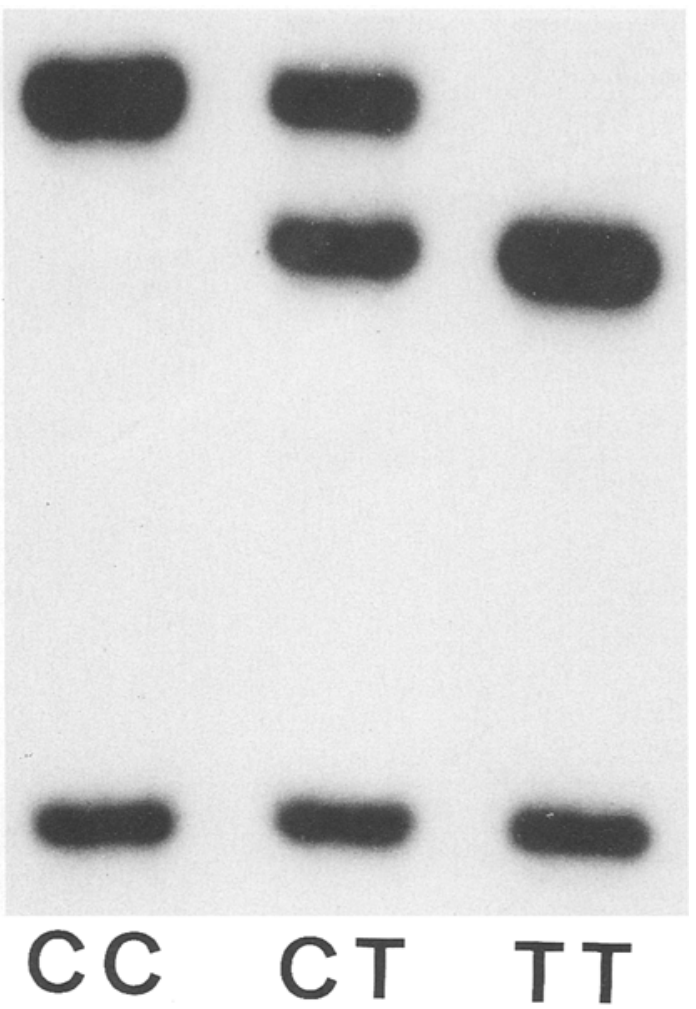

Fig. 4 A-C. SSCP variants resulting from nucleotide substitutions in exons 4,7 and 16 . SSCP analysis in $5 \%$-polyacrylamide gel containing 5\% glycerol. A Exon 4; B Exon 7; C Exon 16

Table 5. Clinical characteristics of the NIDDM patients and control subjects divided into groups according to Gln/His polymorphism at the amino acid 142 of the HK2

\begin{tabular}{|c|c|c|c|c|}
\hline $\begin{array}{l}\text { Subjects } \\
\text { Genotypes }\end{array}$ & \multicolumn{2}{|l|}{ NIDDM } & \multicolumn{2}{|l|}{ Control subjects } \\
\hline Age (years) & $70 \pm 12$ & $69 \pm 7$ & $53 \pm 13$ & $48 \pm 14$ \\
\hline Fasting blood glucose (mmol/l) & $8.9 \pm 2.7$ & $9.6 \pm 3.3$ & $5.0 \pm 0.5$ & $4.9 \pm 0.5$ \\
\hline Fasting serum insulin (pmol/l) & $111 \pm 62$ & $134 \pm 193$ & $54 \pm 32$ & $48 \pm 17$ \\
\hline $\mathrm{BMI}\left(\mathrm{kg} / \mathrm{m}^{2}\right)$ & $28.4 \pm 4.4$ & $26.7 \pm 3.2$ & $26.3 \pm 4.0$ & $24.7 \pm 3.7$ \\
\hline Serum triglycerides $(\mathrm{mmol} / \mathrm{l})$ & $2.29 \pm 1.41$ & $1.87 \pm 0.97$ & $1.10 \pm 0.45$ & $1.36 \pm 0.94$ \\
\hline Serum HDL cholesterol (mmol/l) & $1.29 \pm 0.37$ & $1.20 \pm 0.24$ & $1.48 \pm 0.36$ & $1.36 \pm 0.34$ \\
\hline Cholesterol (mmol/1) & $6.30 \pm 1.47$ & $5.80 \pm 1.76$ & $5.68 \pm 1.42$ & $5.35 \pm 1.52$ \\
\hline
\end{tabular}

Results are given as mean \pm SD

from Table 6 , there was no difference in hexokinase enzyme activities between these groups suggesting that this codon 142 polymorphism is unlikely to have an effect to the HK2 enzyme activity in muscle. Of note, total hexokinase $(r=0.52 ; p<0.0001)$ and HK2 $(r=0.55 ; p<0.0003)$ enzyme activities correlated in- versely with the fasting blood glucose concentration (Fig. 5). There was, however, no correlation between the hexokinase activities and the M-value (insulin stimulated glucose uptake) measured during the clamp. 


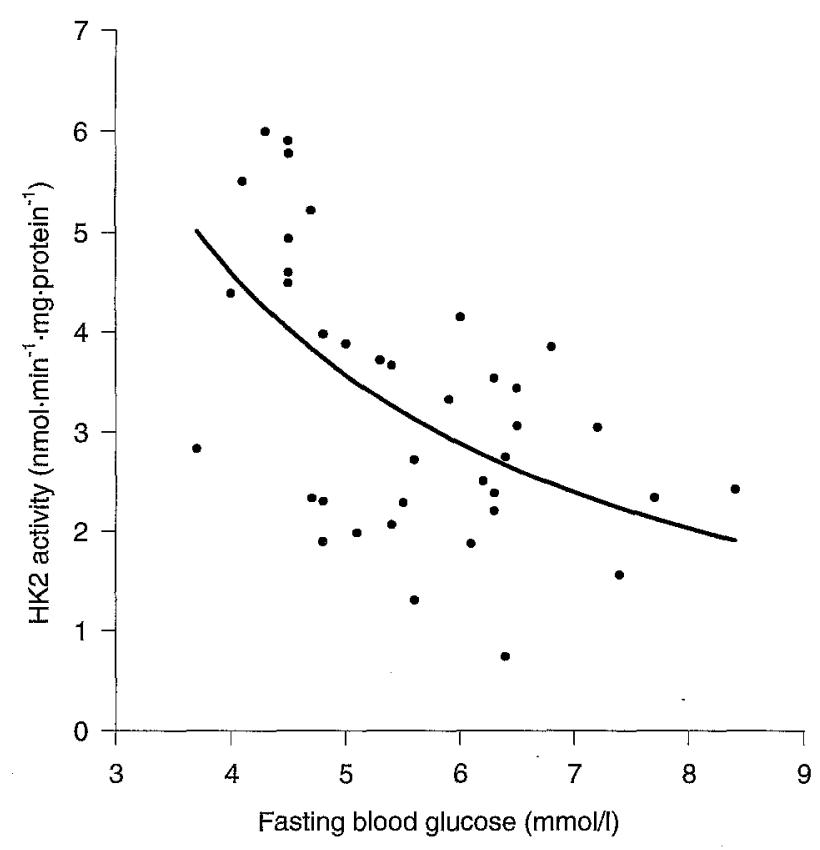

Fig. 5. Relationship between HK2 activity and fasting blood glucose in 39 subjects with different degree of glucose intolerance. $R=0.55, p=0.0003$

Table 6. Hexokinase enzyme activities in muscle subgrouped according to the codon 142 polymorphism in IGT subjects

\begin{tabular}{|c|c|c|}
\hline $\begin{array}{l}\text { Genotypic variants }(n) \\
\text { HK2 gene; codon } 142\end{array}$ & $\mathrm{G} \ln / \mathrm{G} \ln (17)$ & $\begin{array}{l}\text { Gln/His (12) } \\
\text { His/His (1) }\end{array}$ \\
\hline $\begin{array}{l}\text { Total protein concentration } \\
(\mathrm{mg} / \mathrm{ml})\end{array}$ & $9.0 \pm 2.1$ & $9.6 \pm 1.9(13.5)$ \\
\hline $\begin{array}{l}\text { Total hexokinase activity } \\
\left(\mathrm{nmol} \cdot \mathrm{min}^{-1} \cdot \mathrm{mg} \text { protein }\right. \\
\end{array}$ & $6.2 \pm 1.6$ & $5.9 \pm 0.8(5.5)$ \\
\hline $\begin{array}{l}\text { HK1 enzyme activity } \\
\left(\mathrm{nmol} \cdot \mathrm{min}^{-1} \cdot \mathrm{mg}^{-1} \text { protein }\right. \\
\end{array}$ & $3.4 \pm 1.0$ & $3.3 \pm 0.9(3.9)$ \\
\hline $\begin{array}{l}\text { HK2 enzyme activity } \\
\left(\mathrm{nmol} \cdot \mathrm{min}^{-1} \cdot \mathrm{mg}^{-1} \text { protein }\right. \\
\end{array}$ & $2.7 \pm 0.8$ & $2.6 \pm 1.0(1.6)$ \\
\hline
\end{tabular}

Results are given as mean \pm SD. Shown in parentheses are values for the homozygous (His/His) IGT subject

\section{Discussion}

Insulin resistance represents an early, probably inherited defect in NIDDM, which can be seen in normoglycaemic offspring of NIDDM parents [15]. Although the molecular causes of insulin resistance are not known, two recent studies have indicated a defect in the enzyme which catalyses phosphorylation of glucose to glucose 6-phosphate i. e. the HK2 step [7, $22]$. We have now provided evidence that the insulin-stimulated HK2 activity is decreased in insulin-resistant individuals with IGT. It remains to be ascertained whether a defect in the HK2 gene causes insulin resistance in NIDDM.

As a first step towards answering this question we determined the exon-intron organization of the human HK2 gene, thereby making SSCP scanning of this gene for mutations possible. In human skeletal muscle, the HK2 mRNA was found to be a single transcript with an estimated length of $\sim 5500$ nucleotides. In rats HK 2 mRNA was $\sim 5300$ nucleotides in length, which agrees well with previous estimates of $\sim 5200$ nucleotides [17]. While this manuscript was in preparation, Malkki et al. [20] and Printz et al. [21] reported the cloning and exon-intron organization of the human HK2 gene. Their results describing the structure of $\mathrm{HK} 2$ are identical to those presented here.

SSCP scanning of all 18 exons of HK 2 gene in 80 unrelated NIDDM patients revealed nine nucleotide substitutions, of which five have been reported recently $[13,23,24]$. In addition, we found two new polymorphisms in the 5 '-untranslated region and two silent polymorphisms in the coding region of the HK2 gene. In keeping with previous reports $[13,23,24]$, we found a missense mutation $\mathrm{Gln}^{142} \mathrm{His}$ exon 4 . The allele frequencies of this amino acid substitution did not differ between NIDDM and control subjects. All NIDDM patients were obese and had high insulin levels indicating insulin resistance. In addition, insulin resistance had been confirmed by a euglycaemic insulin clamp in one-third of the patients. The insulin values in the individuals with genotypes Gln/Gln, $\mathrm{Gln} / \mathrm{His}$ and His/His in position 142 did not differ, it is therefore unlikely that this amino acid contributes to the development of the insulin resistance in these NIDDM patients. However, in patients with manifest NIDDM, insulin resistance can be the consequence of glucose toxicity (metabolic insulin resistance) as well as of a genetic defect [25]. To partially circumvent this problem, we studied an additional group of non-diabetic subjects, measuring hexokinase activity in skeletal muscle biopsies taken at the end of a euglycaemic clamp. Despite similar age and degree of obesity, the IGT subjects had significantly decreased hexokinase activity. Nevertheless, our data do not support the view that insulin resistance in the IGT subjects is the consequence of a genetic defect in the HK2 gene. First, if anything, hexokinase activity was higher in the IGT subjects with, than those without, a first-degree family history of NIDDM. This could represent a mechanism to compensate for a defect distal to the phosphorylation step. Second, the hexokinase enzyme activities did not differ between individuals with $\mathrm{Gln}^{142}$ or His ${ }^{142}$ alleles. Third, the hexokinase activity showed a strong inverse correlation with the fasting glucose concentrations, suggesting that the decrease in the hexokinase activity could be a consequence of the metabolic derangement rather than of a genetic abnormality.

In conclusion, the data suggest that decreased hexokinase activity in prediabetic insulin-resistant individuals is secondary to glucose intolerance rather than to genetic alterations in the HK2 gene. It is thus unlikely that the HK2 gene represents a major cause of inherited insulin resistance in NIDDM. 
Acknowledgements. These studies were supported by grants from the Medical Faculty, University of Lund and Påhlsson Foundation (to ML), the Juselius Foundation, Finland and Swedish Medical Research Council (10858 to LG), and from the United States Public Health Service (CA-40046 to MML and DK-20595 to GIB), and the Howard Hughes Medical Institute.

\section{References}

1. Katzen HM, Schimke RT (1965) Multiple forms of hexokinase in the rat: tissue distribution, age dependency, and properties. Proc Natl Acad Sci USA 54: 1218-1225

2. Vionnet N, Stoffel M, Takeda J et al. (1992) Nonsense mutation in the glucokinase gene causes early-onset non-insulin-dependent diabetes mellitus. Nature 356: 721-722

3. Stoffel M, Froguel Ph, Takeda J et al. (1992) Human glucokinase gene: isolation, characterization, and identification of two missense mutations linked to early-onset noninsulin-dependent (type 2) diabetes mellitus. Proc Nat1 Acad Sci USA 89: 7698-7702

4. Gidh-Jain M, Takeda J, Xu LZ et al. (1993) Glucokinase mutations associated with non-insulin-dependent (type 2) diabetes mellitus have decreased enzymatic activity: implications for structure/function relationships. Proc Natl Acad Sci USA 90: 1932-1936

5. Pilkis SJ, Weber IT, Harrison RW, Bell GI (1994) Glucokinase: structural analysis of a protein involved in susceptibility to diabetes. J Biol Chem 269: 21925-21928

6. Beck-Nielsen H, Groop LC (1994) Metabolic and genetic characterization of prediabetic states. J Clin Invest 94: 1714-1721

7. Rothman DL, Shulman RG, Shulman GI (1992) Nuclear magnetic resonance measurements of muscle glucose-6phosphate. J Clin Invest 89: 1069-1075

8. Lehto M, Xiang K, Stoffel M et al. (1993) Human hexokinase II: localization of the polymorphic gene to chromosome 2. Diabetologia 36: 1299-1302

9. Lehto M, Cox N, Le Beau M, Groop L (1993) Localization of the polymorphic human hexokinase II (HK 2) gene to chromosome 2 and linkage studies in families with NIDDM. Diabetes 42 [Suppl 1] 19A (Abstract)

10. Vaxillaire M, Vionnet N, Vigouroux C et al. (1994) Search for a third susceptibility gene for maturity-onset diabetes of the young. Diabetes 43: 389-395

11. Rowley JD, Diaz MO, Espinosa R et al. (1990) Mapping chromosome band $11 \mathrm{q} 23$ in human acute leukemia with bionylated probes: identification of 11q23 translocation breakpoints with a yeast artificial chromosome. Proc Natl Acad Sci USA 87: 9358-9362
12. Orita M, Suzuki Y, Sekiya T, Hayashi K (1989) Rapid and sensitive detection of point mutations and DNA polymorphism using the polymerase chain reaction. Genomics 5: 874-879

13. Echwald SM, Björbak C, Hansen T et al. (1995) Identification of four amino acid substitutions in hexokinase II and studies of relationship to NIDDM, glucose effectiveness, and insulin sensitivity. Diabetes 44: 347-353

14. Sambrook J, Fritsch EF, Maniatis T (1989) Molecular cloning, a laboratory manual, 2nd edn. Cold Spring Harbor Laboratory Press, Cold Spring Harbor, NY

15. Eriksson J, Franssila-Kallunki A, Ekstrand A et al. (1989) Early metabolic defects in persons at increased risk for non-insulin-dependent diabetes mellitus. N Engl J Med 321: $337-343$

16. Lowry OH, Rosenbrough NJ, Farr AL, Randall RJ (1951) Protein measurement with the Folin phenol reagent. J Biol Chem 260: 265-275

17. Thelen AP, Wilson JE (1991) Complete amino acid sequence of the type II isoenzyme of rat hexokinase, deduced from the cloned cDNA: comparison with a hexokinase from Novikoff ascites tumor. Arch Biochem Biophys 266: 645-651

18. Deeb SS, Malkki M, Laakso M (1993) Human hexokinase II: sequence and homology to other hexokinases. Biochem Biophys Res Comm 194: 68-74

19. Printz RL, Koch S, Potter LR et al. (1993) Hexokinase II mRNA and gene structure, regulation by insulin, and evolution. J Biol Chem 268: 5209-5219

20. Malkki M, Laakso M, Deeb SS (1994) Structure of the human hexokinase II gene. Biochem Biophys Res Commun 205: 490-496

21. Printz RL, Ardehali H, Koch S, Granner DK (1995) Human hexokinase II $\mathrm{mRNA}$ and gene structure. Diabetes 44: 290-294

22. Bonadonna RC, Del Prato S, Saccomani MP (1993) Transmembrane glucose transport in skeletal muscle of patients with non-insulin-dependent diabetes. J Clin Invest 92: 486-494

23. Vidal-Puig A, Printz RL, Stratton IM, Granner DK, Moller DE (1995) Analysis of the hexokinase II gene in subjects with insulin resistance and NIDDM and detection of a $\mathrm{Gln}^{142}>$ His substitution. Diabetes 44: $340-346$

24. Laakso M, Malkki M, Deeb SS (1995) Amino acid substitutions in hexokinase II among patients with NIDDM. Diabetes 44: 330-334

25. Yki-Järvinen H (1990) Acute and chronic effects of hyperglycemia on ghucose metabolism. Diabetologia 33: 579-585 